\title{
Biomimetic, smart and multivalent ligands for G-quadruplex isolation and bioorthogonal imaging
}

\author{
Francesco Rota Sperti, Thibaut Charbonnier, Pauline Lejault, Joanna Zell, \\ Claire Bernhard, Ibai E. Valverde ${ }^{\star}$ and David Monchaud ${ }^{\star}$ \\ ICMUB, CNRS UMR6302, UBFC Dijon, 9, Avenue Alain Savary, 21078 Dijon, France \\ E-mail : ibai.valverde@u-bourgogne.fr, david.monchaud@cnrs.fr
}

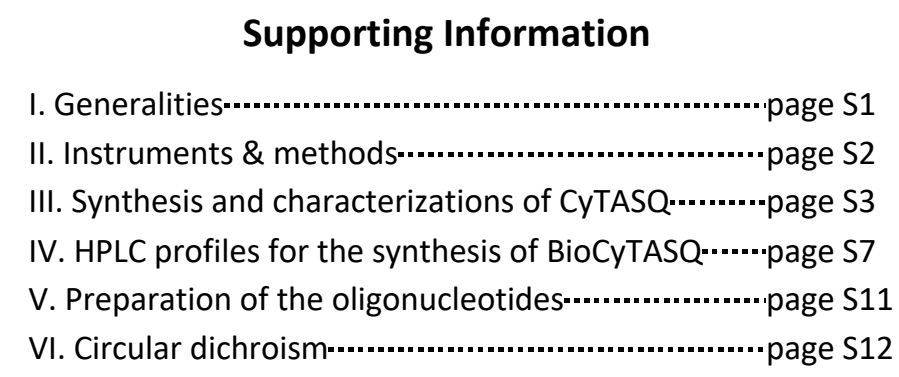

\section{Generalities.}

TSTU was purchased from Iris Biotech $\mathrm{GmbH}$. Solvents were purchased from VWR or Carlo Erba. All other chemicals were from Sigma Aldrich, Acros organics, or Fisher Scientific. Cyclen was a gift from Chematech (Dijon, France). Media and supplements for cell culture were bought from Dustcher SAS. Unless noted otherwise, all commercially available reagents and solvents were used without further purification. Dicalite was purchased from Carlo Erba. TLC were carried out on Merck DC Kieselgel 60 F-254 aluminum sheets. The spots were directly visualized via staining with ninhydrin or through illumination with a UV lamp $(\lambda=254 \mathrm{~nm})$. Column chromatography purifications were performed manually on silica gel (40-63 $\mu \mathrm{m})$ from Sigma-Aldrich (technical grade). Dry $\mathrm{CH}_{2} \mathrm{Cl}_{2}$ (HPLC-grade) was dried over alumina cartridges using a solvent purification system PureSolv PS-MD-5 model from Innovative Technology. HPLC-gradient grade $\mathrm{CH}_{3} \mathrm{CN}$ used for HPLC-MS analyses was obtained from Carlo Erba. $\mathrm{CH}_{3} \mathrm{CN}$ used in semi-preparative RP-HPLC purifications was obtained from VWR (technical, $+99 \%$ but distilled prior to use). All aq. mobile-phases for HPLC were prepared using water purified with a PURELAB Ultra system from ELGA (purified to $18.2 \mathrm{M} \Omega . \mathrm{cm}$ ). Yields were calculated based on isolation of the compounds. 


\section{Instruments and methods.}

Lyophilization was performed with a Christ Alpha 2-4 LD plus. ${ }^{1} \mathrm{H}-$, and ${ }^{13} \mathrm{C}-\mathrm{NMR}$ spectra were recorded on Bruker spectrometers, an Avance Neo $500 \mathrm{MHz}$ equipped with a $5 \mathrm{~mm}$ BBOF iProbe and Avance III HD $600 \mathrm{MHz}$ equipped with a $5 \mathrm{~mm} \mathrm{BBOF} \mathrm{N}_{2}$ cryoprobe. Chemical shifts are expressed in parts per million (ppm) from the residual non-deuterated solvent signal summarized in 2010 by Fulmer et al. (Organometallics 2010, 29, 2176-2179) J values are expressed in $\mathrm{Hz}$. Coupling constants $(J)$ are reported in hertz $(\mathrm{Hz})$. Standard abbreviations indicating multiplicity were used as follows: $\mathrm{s}=$ singlet, $\mathrm{d}=$ doublet, $\mathrm{t}=$ triplet, $\mathrm{q}=$ quadruplet, $\mathrm{m}=$ multiplet, $\mathrm{br}=$ broad. High-resolution mass spectrometry analyses were recorded on a LTQ Orbitrap XL mass spectrometer (Thermo Scientific) equipped with an electrospray ionization source (HESI 2). The following source parameters were used if no further specification is mentioned: Heater Temperature: $50^{\circ} \mathrm{C}$, Gas Flow: Sheath 15 / Aux 10 / Sweep 0 , Spray Voltage: 4 kV, Capillary Temperature: $275^{\circ} \mathrm{C}$, Capillary Voltage: 22 V, Resolution (m/z $=400): 60$ 000. HPLC-MS analyses were performed on a Thermo-Dionex Ultimate 3000 instrument (pump + autosampler at $20^{\circ} \mathrm{C}+$ column oven at $25^{\circ} \mathrm{C}$ ) equipped with a diode array detector (Thermo-Dionex DAD 3000-RS) and a MSQ Plus single quadrupole mass spectrometer. The corresponding low-resolution mass spectra (LRMS) were recorded with this latter mass spectrometer, with an electrospray (ESI) source (HPLC-MS coupling mode). HPLC systems were equipped with a Phenomenex Kinetex C18 column, 2.6 $\mu \mathrm{m}, 2.1 \times 50 \mathrm{~mm}$ or a Jupiter Proteo $4 \mu \mathrm{m}$ 90Å column, $250 \times 4.6 \mathrm{~mm}$. Two analytical methods: Method A: from 5\% to $100 \% \mathrm{MeCN} / \mathrm{H}_{2} \mathrm{O}+0.1 \%$ formic acid (FA) in $7 \mathrm{~min}$; Method $\mathrm{B}$ : from $5 \%$ to $15 \%$ $\mathrm{MeCN} / \mathrm{H}_{2} \mathrm{O}+0.1 \% \mathrm{FA}$ in $5 \mathrm{~min}$, from $15 \%$ to $70 \% \mathrm{MeCN} / \mathrm{H}_{2} \mathrm{O}+0.1 \% \mathrm{FA}$ in $20 \mathrm{~min}$, from $70 \%$ to $100 \% \mathrm{MeCN} / \mathrm{H}_{2} \mathrm{O}+0.1 \% \mathrm{FA}$ in $3 \mathrm{~min}$. Purifications by semi-preparative HPLC were performed on a Thermo-Dionex Ultimate 3000 instrument equipped with a RS Variable Detector (four distinct wavelengths). HPLC system was equipped with a Jupiter Proteo $4 \mu \mathrm{m} 90 \AA ̊$ column (250 x $21.2 \mathrm{~mm}$, AXIA packed). 
III. Synthesis and characterizations of CyTASQ.

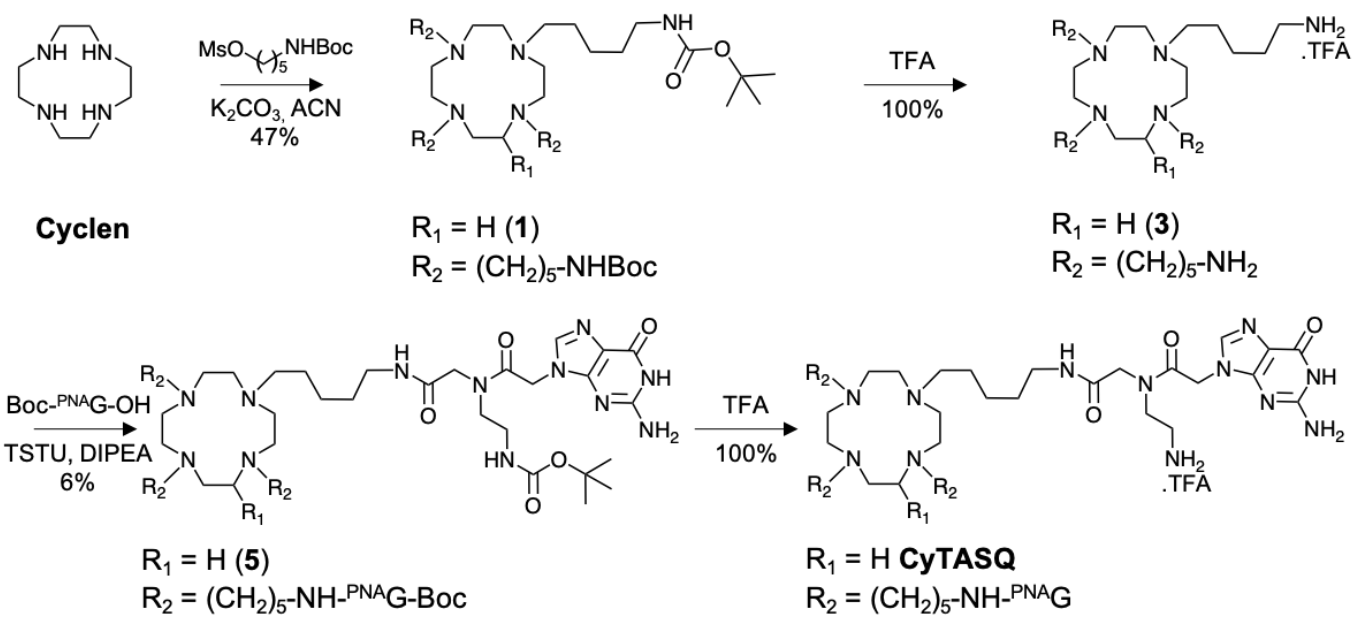

Figure S1. Synthesis of CyTASQ

Compound 1: To a solution of cyclen (30 mg, $0.20 \mathrm{mmol}, 1.0$ equiv.) in acetonitrile $(1.16 \mathrm{~mL})$ was added 5-((tert-butoxycarbonyl)amino)pentyl methanesulfonate $(400 \mathrm{mg}, 1.40 \mathrm{mmol}, 7.0$ equiv.) and $\mathrm{K}_{2} \mathrm{CO}_{3}(191 \mathrm{mg}, 1.40 \mathrm{mmol}, 7.0$ equiv.) and the solution was stirred until complete conversion of the starting material (48h, monitoring by RP-HPLC). The crude mixture was filtered, and concentrated under vacuum. The residue was then purified by silica gel column chromatography $\left(\mathrm{CH}_{2} \mathrm{Cl}_{2} / \mathrm{MeOH}(90: 10)\right)$. After evaporation of the solvents, compound 1 was obtained (74.2 mg, $0.08 \mathrm{mmol}, 47 \%$ yield). ${ }^{1} \mathrm{H} \mathrm{NMR}\left(500 \mathrm{MHz}, \mathrm{CDCl}_{3}\right.$ ): $\delta 4.85$ (br s, 4H), 3.12$3.08(\mathrm{~m}, 8 \mathrm{H}), 2.98-2.83(\mathrm{~m}, 16 \mathrm{H}), 2.77-2.67(\mathrm{~m}, 8 \mathrm{H}), 1.54-1.49(\mathrm{~m}, 16 \mathrm{H}), 1.43(\mathrm{~s}, 36 \mathrm{H}), 1.34-$ 1.28 (m, 8H). ESI-MS: $[\mathrm{M}+\mathrm{H}]^{+} \mathrm{m} / \mathrm{z}=914.0$ (calcd. for $\mathrm{C}_{48} \mathrm{H}_{97} \mathrm{~N}_{8} \mathrm{O}_{8}: 914.3$ ). HPLC-MS (Method A): retention time $=6.23$ min; purity: $>91 \%$ at $201 \mathrm{~nm} ; \mathrm{m} / \mathrm{z}=914.0[\mathrm{M}+\mathrm{H}]^{+}$(Fig. S2).
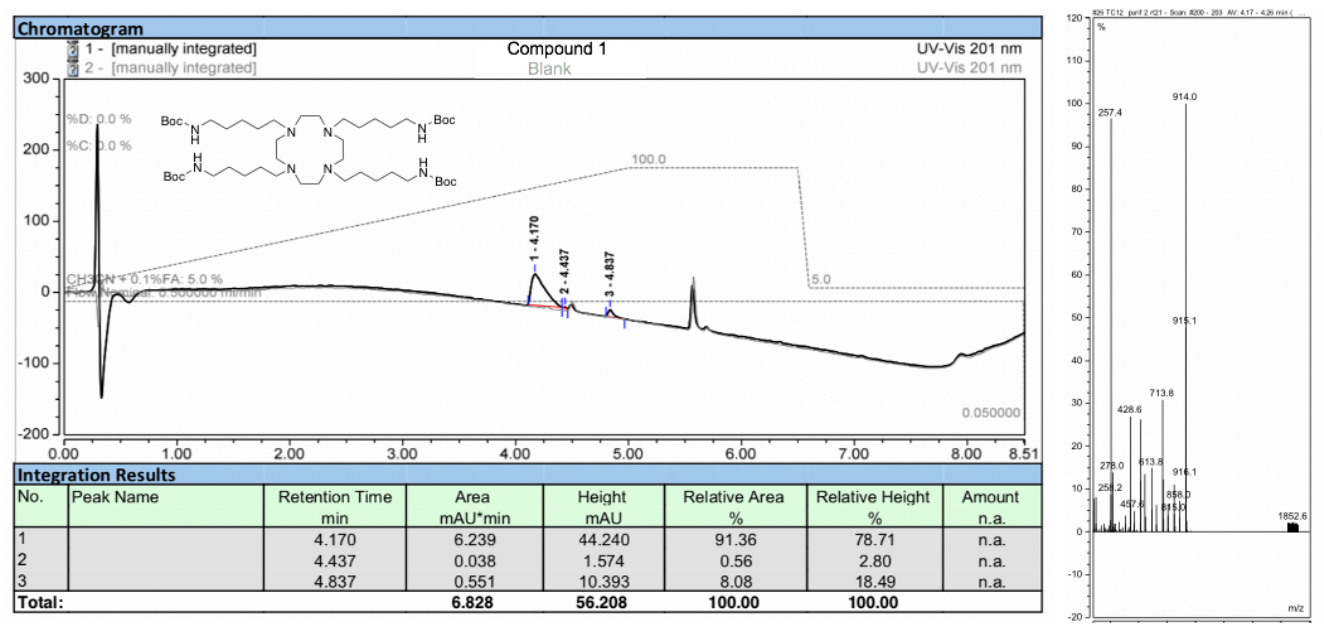

Figure S2. HPLC-MS profile of Compound 1 
Compound 3: compound 1 was stirred in $2 \mathrm{~mL}$ of TFA for 1 hour. After evaporation of the TFA, compound 3 was obtained $\left(78.5 \mathrm{mg}, 0.08 \mathrm{mmol}, 100 \%\right.$ yield), ESI-MS: $[\mathrm{M}+\mathrm{H}]^{+} \mathrm{m} / \mathrm{z}=514.5$ (calcd. for $\mathrm{C}_{28} \mathrm{H}_{65} \mathrm{~N}_{8}: 513.8$ ). HPLC-MS (Method A): retention time $=0.32 \mathrm{~min}$; purity: $>88 \%$ at $201 \mathrm{~nm},>98 \%$ at $214 \mathrm{~nm} ; \mathrm{m} / \mathrm{z}=513.5[\mathrm{M}]^{+}$(Figure S3).
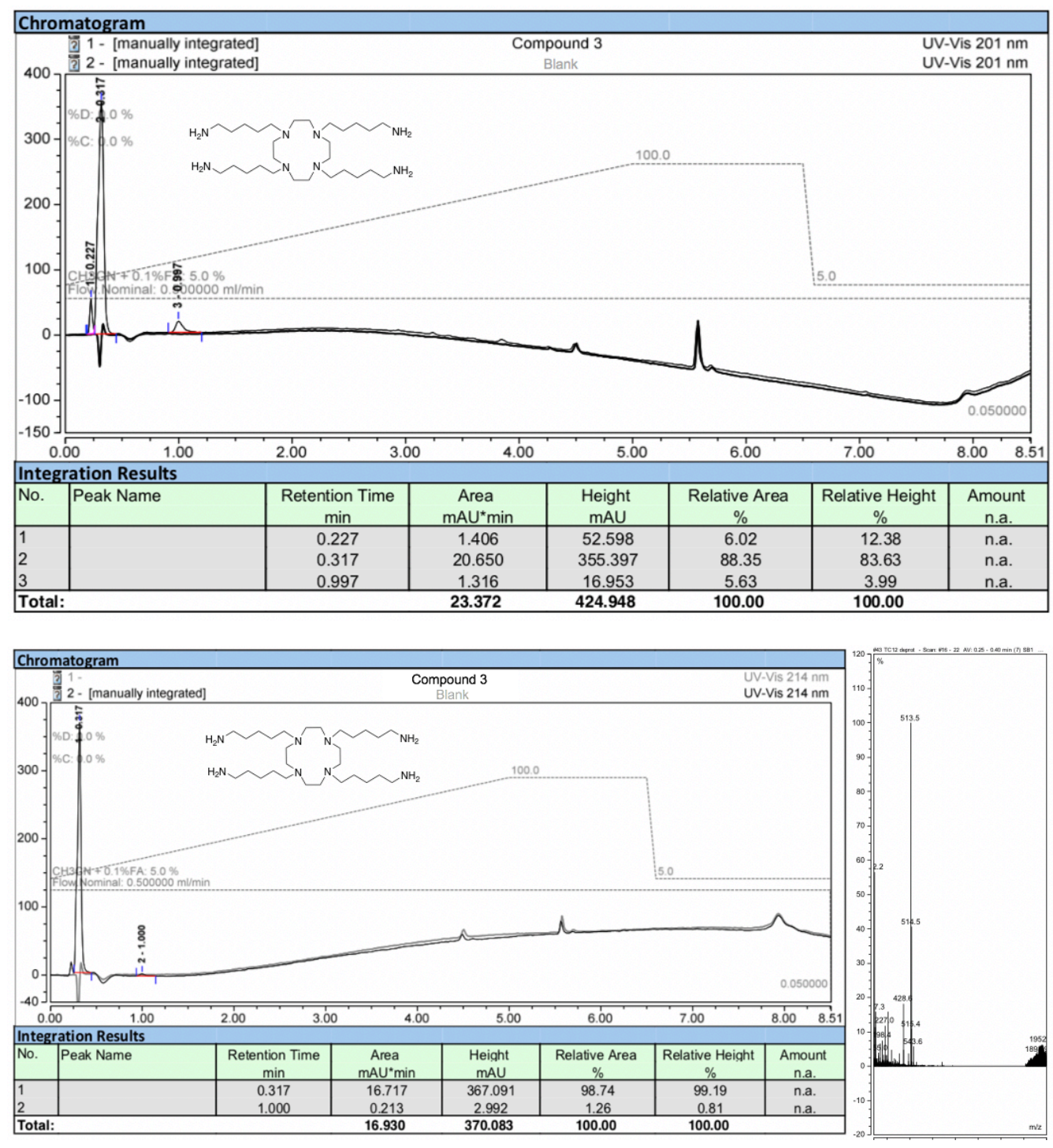

Figure S3. HPLC and HPLC-MS profiles of Compound 3

Compound 5: Boc- ${ }^{\mathrm{PNA}} \mathrm{G}-\mathrm{OH}(160 \mathrm{mg}, 0.40 \mathrm{mmol}, 4.5$ equiv.) and TSTU (118 mg, $0.40 \mathrm{mmol}, 4.5$ equiv.) were dissolved in DMF ( $1 \mathrm{~mL}$ ) and DIPEA was added (54 $\mu \mathrm{L}, 0.36 \mathrm{mmol}, 4.0$ equiv.). After $1 \mathrm{~h}$, a solution of compound 3 ( $45 \mathrm{mg}, 0.09 \mathrm{mmol}, 1.0$ equiv.) and DIPEA (54 $\mu \mathrm{L}, 0.36$ mol, 4.0 equiv.) in DMF (1 mL) was added and the mixture was stirred at RT for 3 days. The solution was then concentrated under vacuum and purified by RP-HPLC in a $\mathrm{H}_{2} \mathrm{O} / \mathrm{ACN}+0.1 \%$ TFA mixture (gradient of 5 to $40 \%$ over $20 \mathrm{~min}$ ). Compound 5 was obtained after removal of 
the solvents (12.3 mg, $0.01 \mathrm{mmol}, 6 \%$ yield). ${ }^{1} \mathrm{H}$ NMR (500 MHz, DMSO- $\left.d 6\right) \delta 10.94(\mathrm{~s}, 4 \mathrm{H})$, 8.44-8.30 (m, 1H), 8.26-8.14 (m, 1H), 7.99-7.84 (m, 7H), 7.03-7.01 (m, 2H), 6.76-6.64 (m, 9H), 5.08-4.84 (m, 8H), 4.19-4.12 (m, 3H), 3.92-3.72 (m, 5H), 3.54-3.47 (m, 5H), 3.29-2.79 (m, 43H), 1.53-1.36 $(\mathrm{m}, 50 \mathrm{H}), 1.27-1.16(\mathrm{~m}, 10 \mathrm{H})$. ESI-MS: $[\mathrm{M}+\mathrm{H}]^{+} \mathrm{m} / \mathrm{z}=2079.17259$ (calcd. for $\mathrm{C}_{92} \mathrm{H}_{149} \mathrm{~N}_{36} \mathrm{O}_{20}$ : 2079.17434). HPLC-MS (Method $A$ ): retention time $=3.63 \mathrm{~min}$; purity: $>86 \%$ at $214 \mathrm{~nm},>82 \%$ at $280 \mathrm{~nm}$ due to the partial deprotection during the HPLC run (labelled with a *, retention time $=3.31 \mathrm{~min}) ; \mathrm{m} / \mathrm{z}=1040.1[\mathrm{M}+\mathrm{H}]^{2+}($ Figure S4).
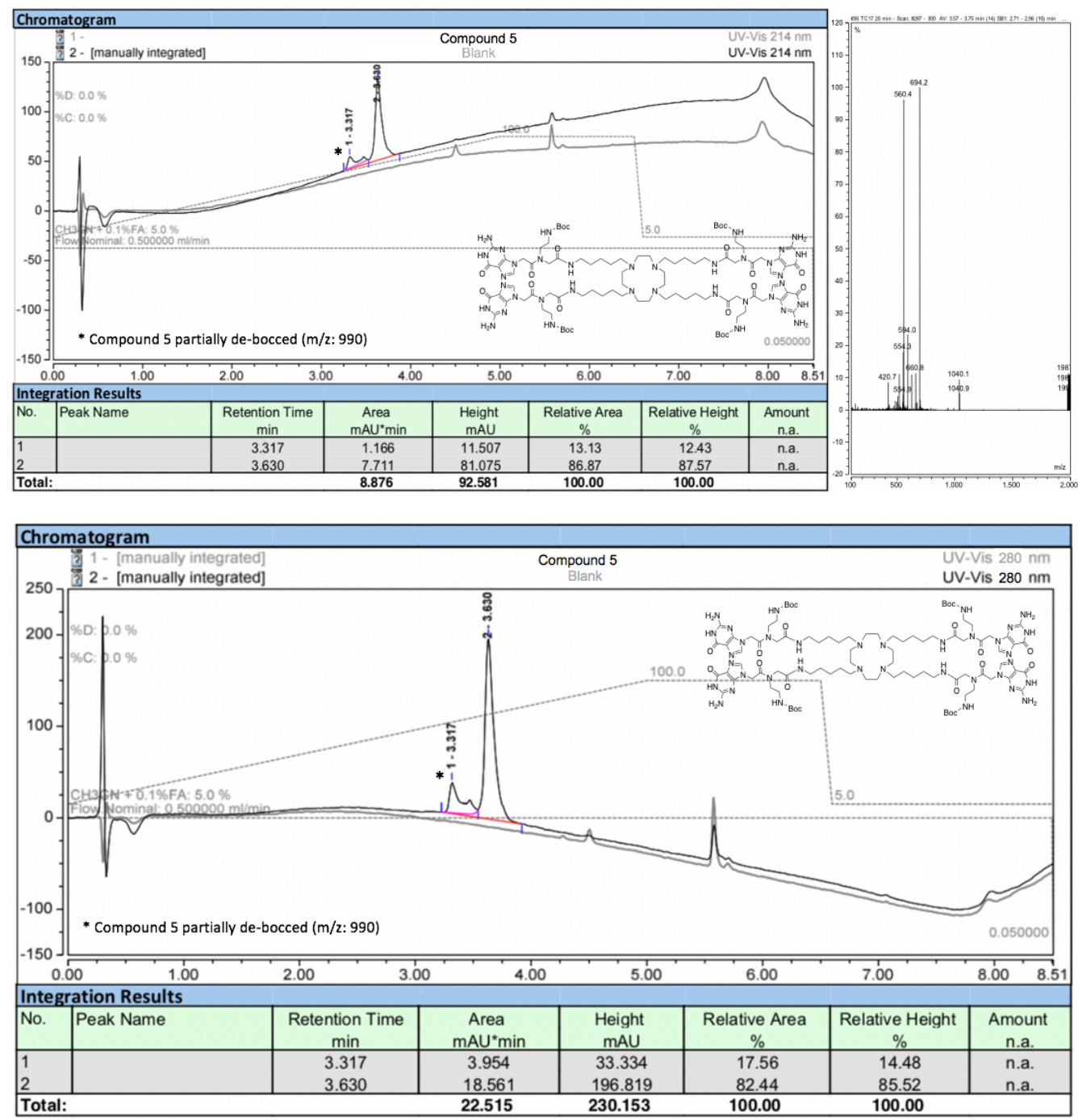

Figure S4. HPLC and HPLC-MS profiles of Compound 5. * partial deprotection during the HPLC run.

CyTASQ: compound 5 was dissolved in $1 \mathrm{~mL}$ of TFA and stirred for 1 hour. The complete deprotection was assessed by HPLC-MS (Method $A$ ); retention time $=0.36 \mathrm{~min} ;[\mathrm{M}+2 \mathrm{H}]^{2+} \mathrm{m} / \mathrm{z}$ = 840.0; calcd. for: $\left.\mathrm{C}_{72} \mathrm{H}_{117} \mathrm{~N}_{36} \mathrm{O}_{12}[\mathrm{M}+2 \mathrm{H}]^{2+} \mathrm{m} / \mathrm{z}=839.9\right)$. TFA was removed under reduced pressure, the residue lyophilized and used immediately. ESI-HRMS: $[\mathrm{M}+\mathrm{H}+\mathrm{Na}]^{2+} \mathrm{m} / \mathrm{z}=$ 
850.47707 (calcd. for $\mathrm{C}_{72} \mathrm{H}_{116} \mathrm{~N}_{36} \mathrm{O}_{12} \mathrm{Na:}$ 850.47692). HPLC-MS (Method A): retention time $=$ $0.36 \mathrm{~min}$; purity: $>94 \%$ at $201 \mathrm{~nm},>98 \%$ at $214 \mathrm{~nm}$ and $>98 \%$ at $280 \mathrm{~nm}$ (Figure S5).
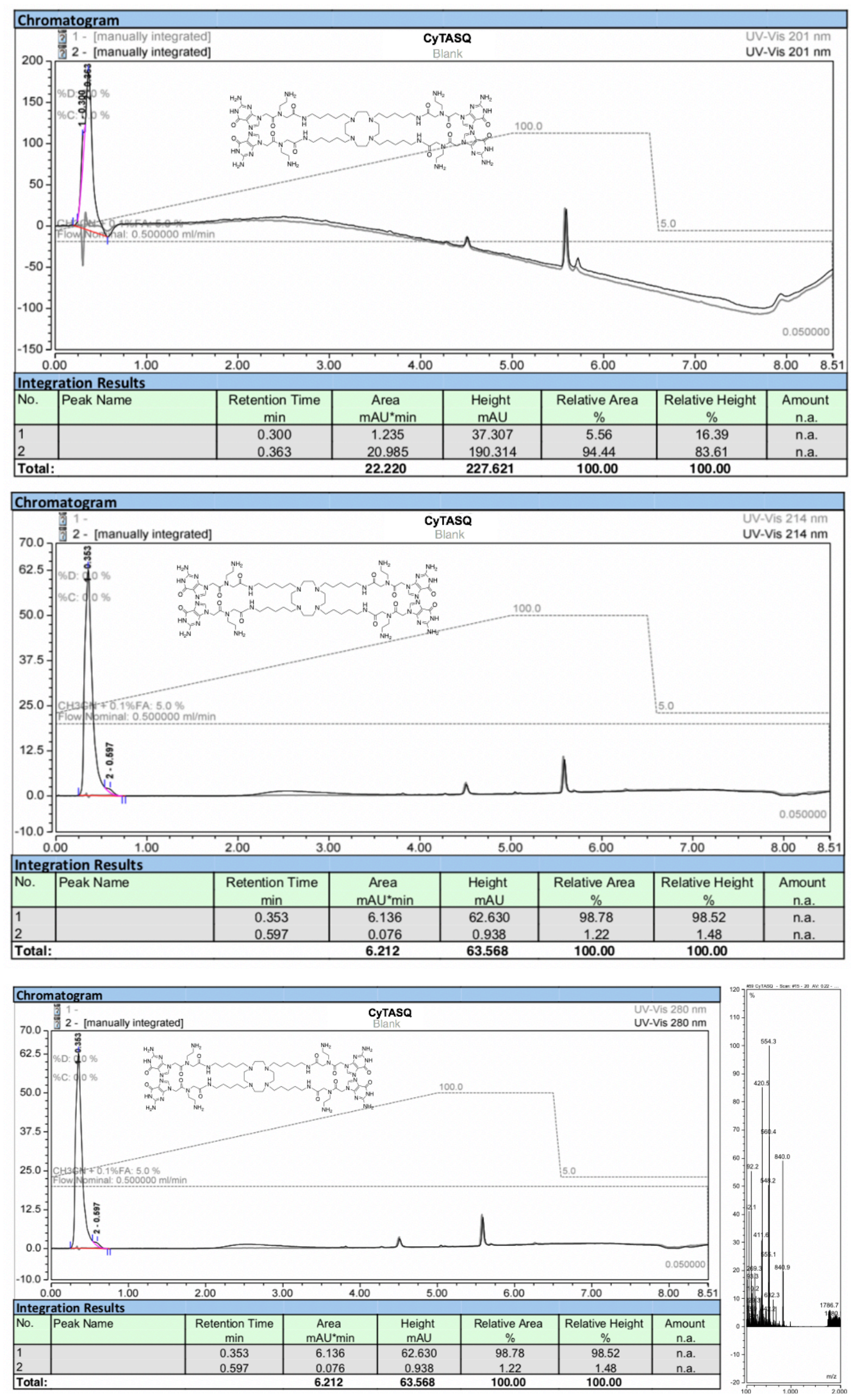

Figure S5. HPLC and HPLC-MS profiles of CyTASQ 
IV. HPLC profiles for the synthesis of BioCyTASQ (see the main text for the description).

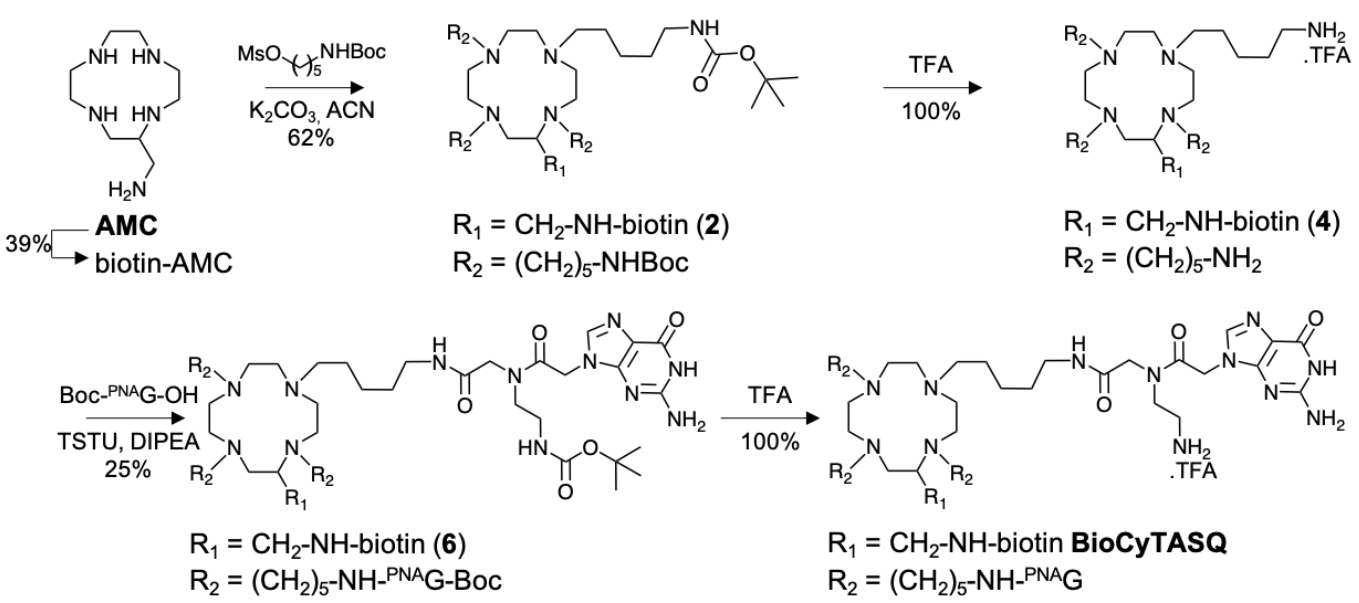

Figure S6. Synthesis of BioCyTASQ
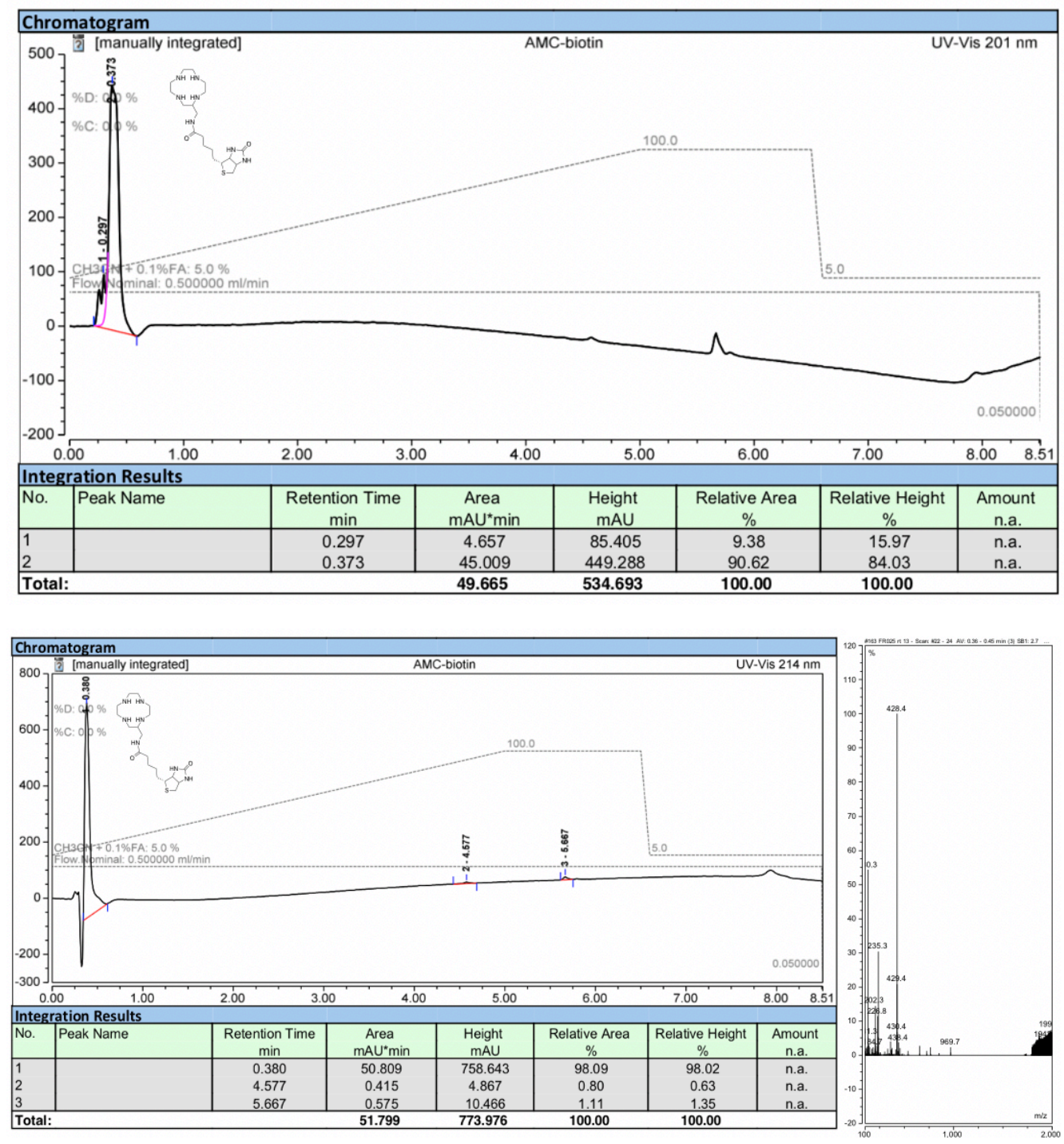

Figure S7. HPLC and HPLC-MS profiles of biotin-AMC 

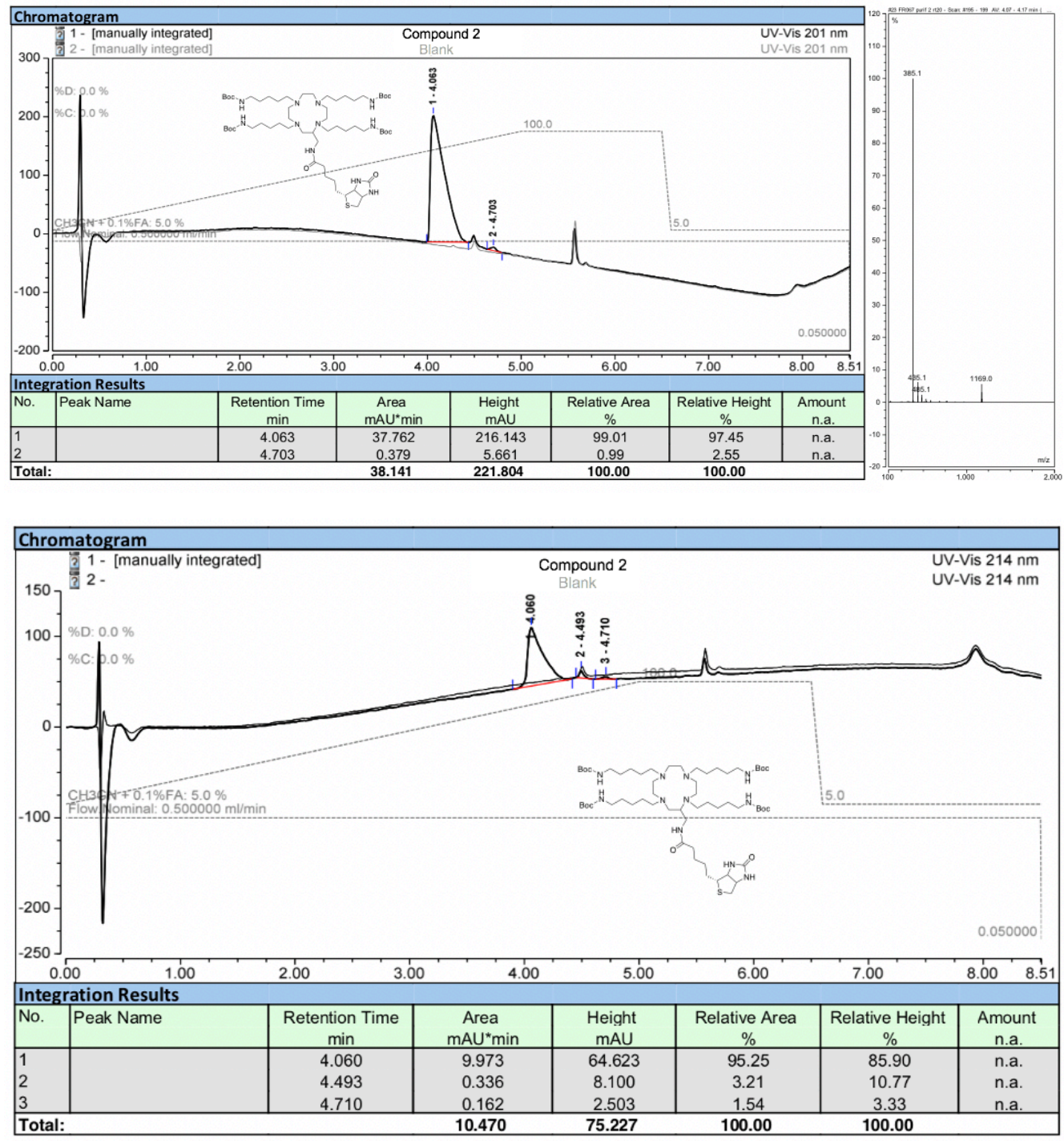

Figure S8. HPLC and HPLC-MS profiles of Compound 2

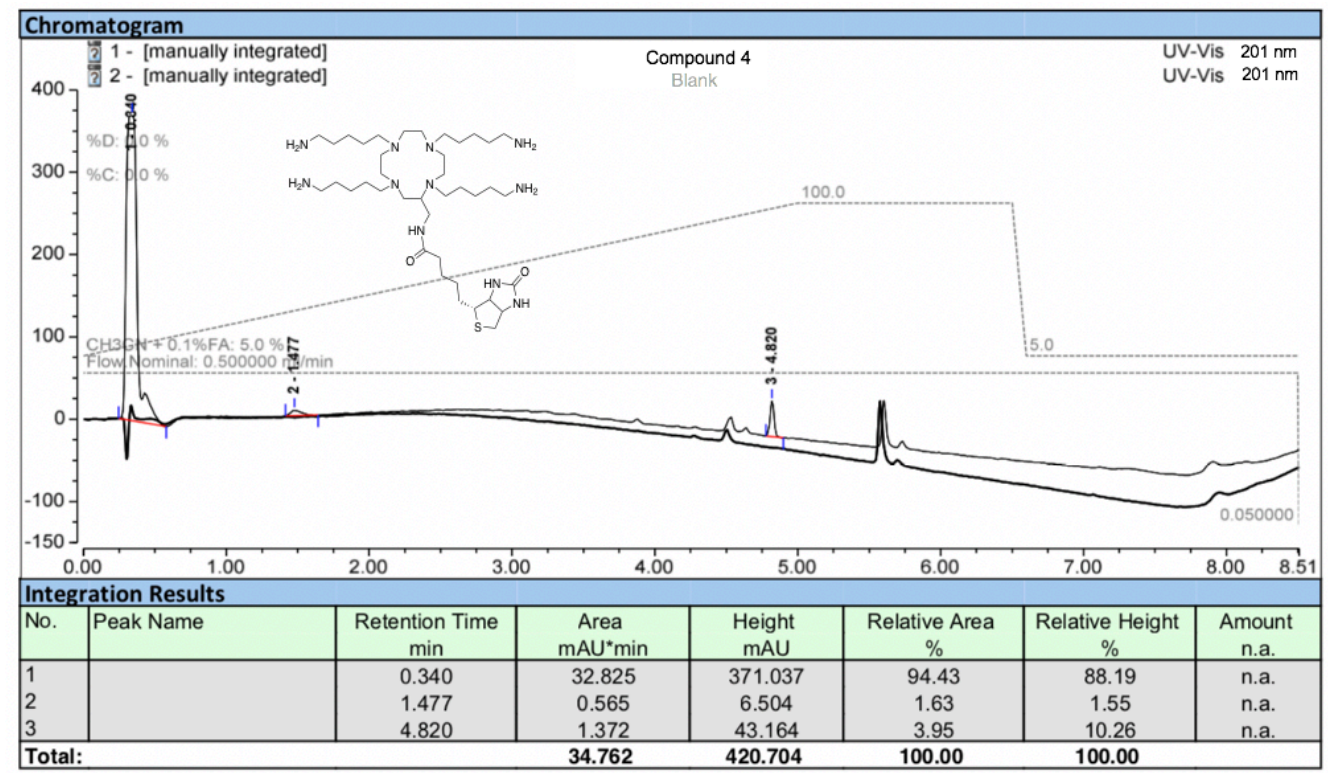




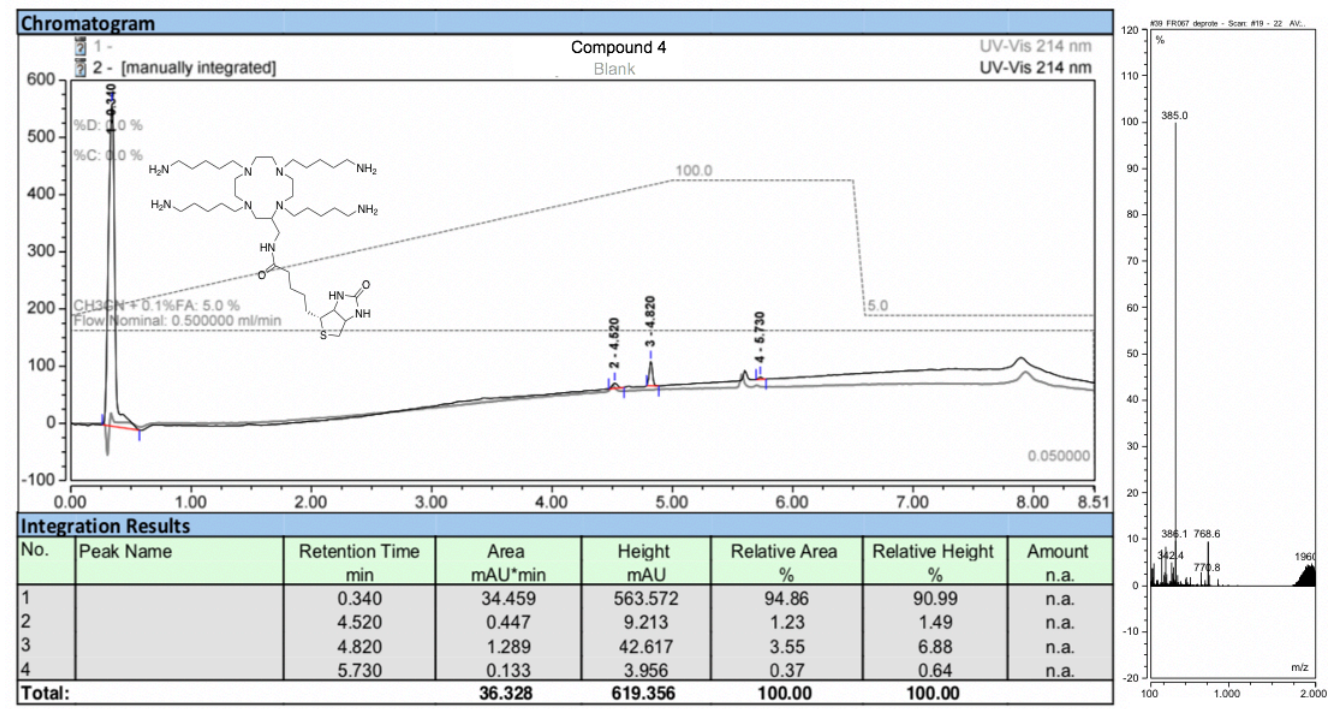

Figure S9. HPLC and HPLC-MS profiles of Compound 4
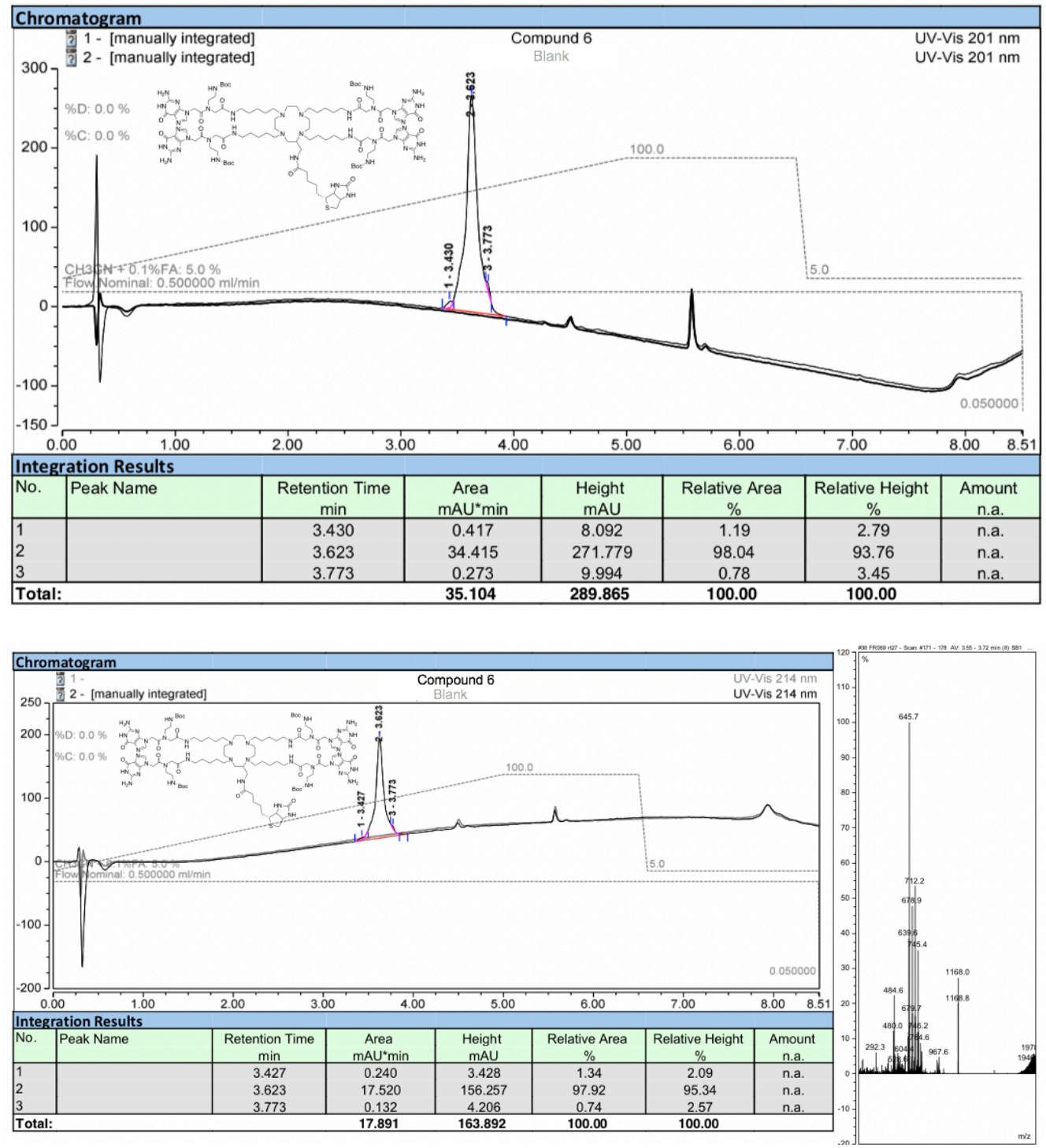

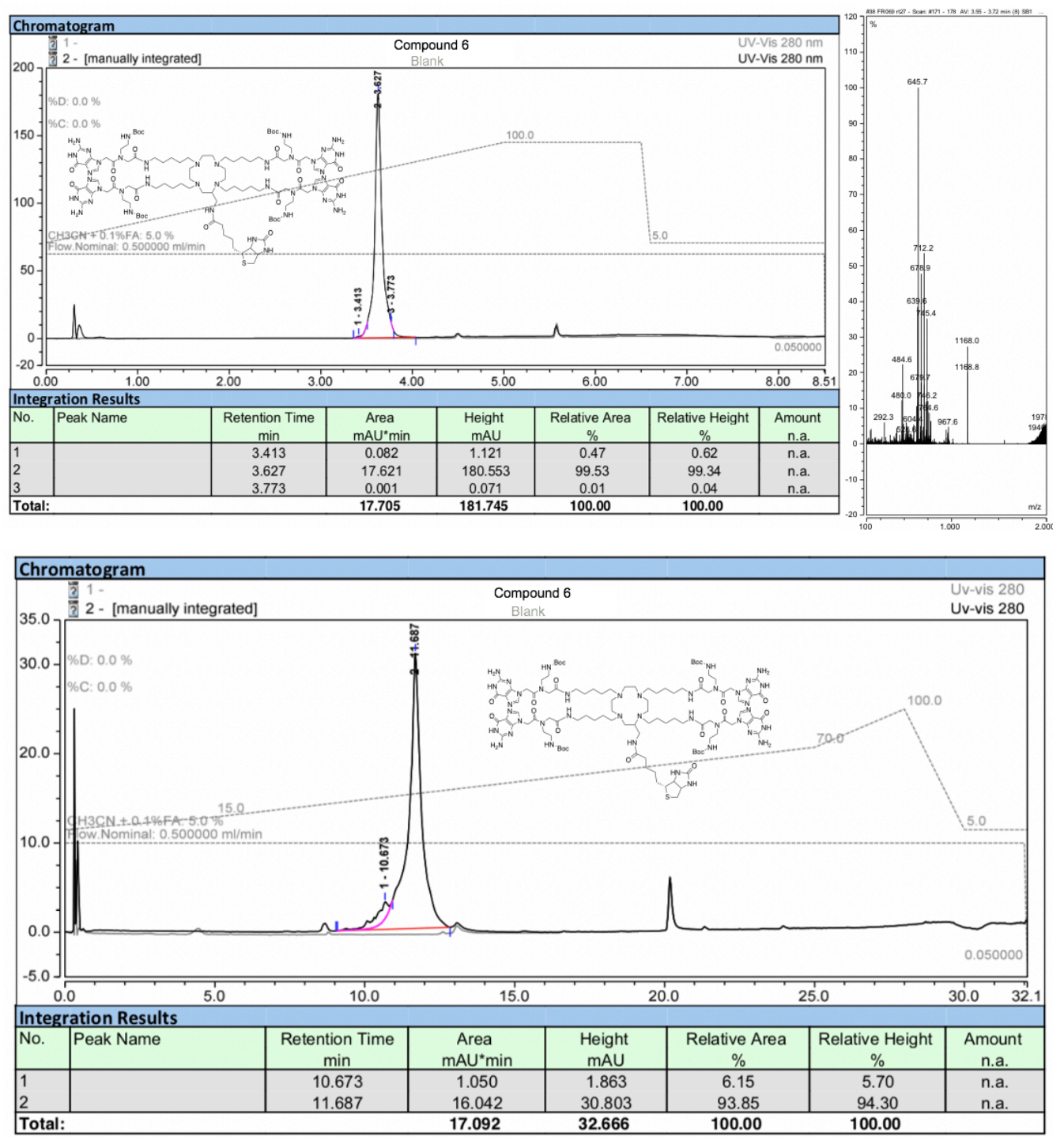

Figure S10. HPLC and HPLC-MS profiles of Compound 6

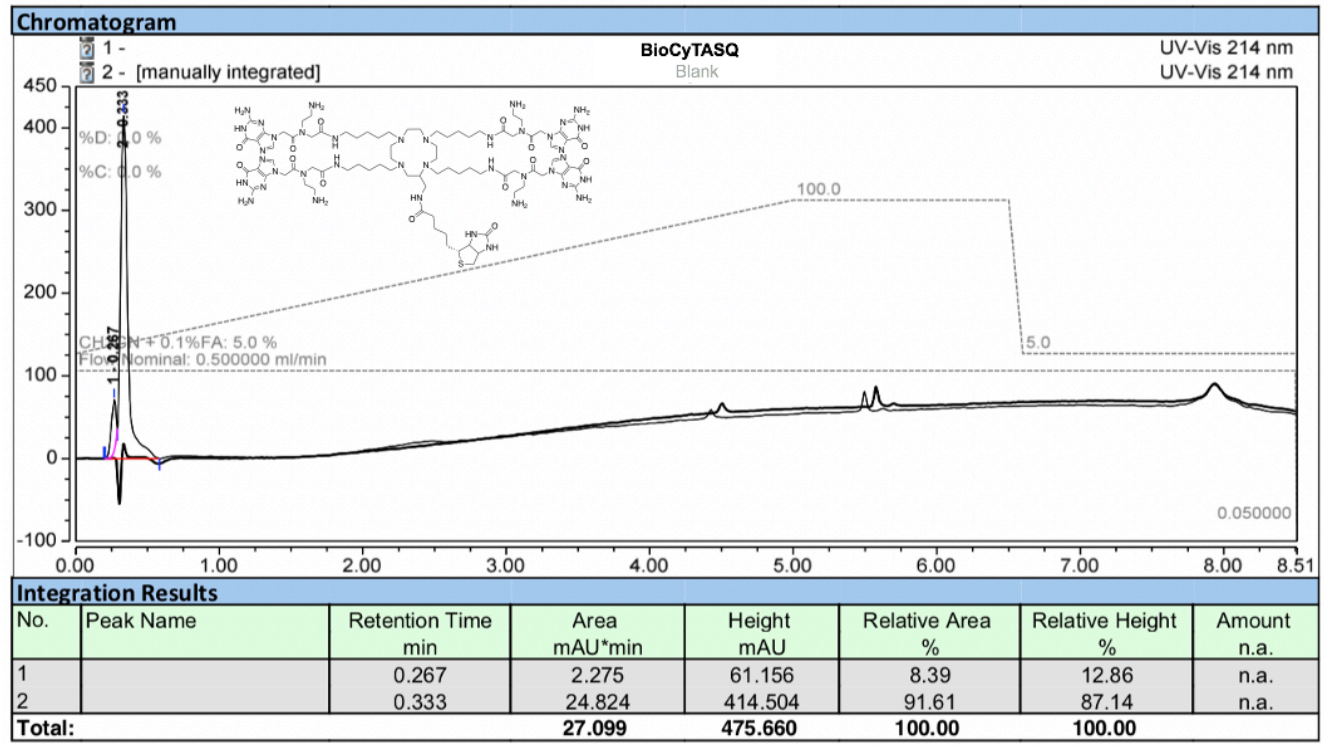



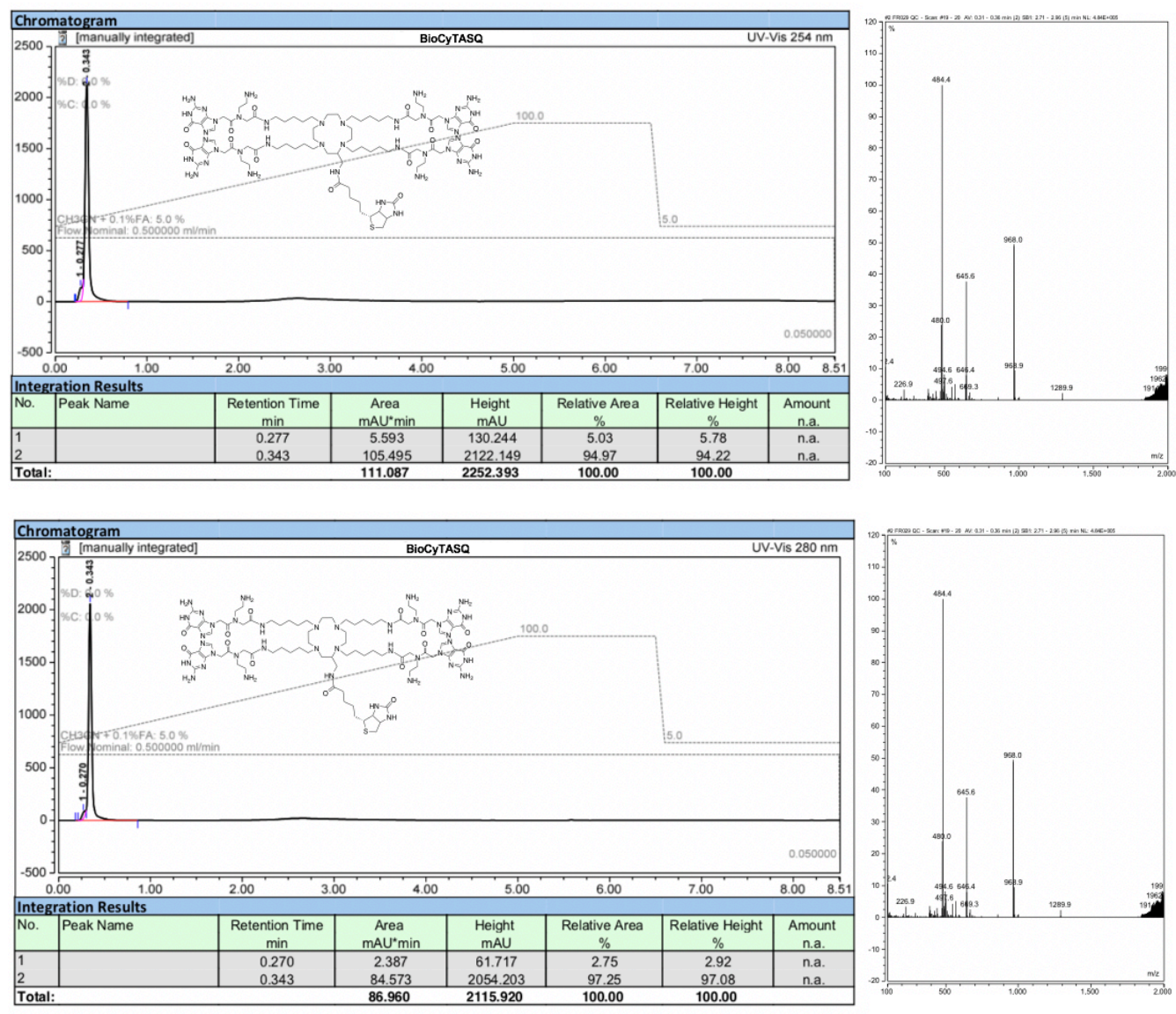

Figure S11. HPLC and HPLC-MS profiles of BioCyTASQ

\section{Preparation of the oligonucleotides.}

Preparation of stock solutions. The lyophilized DNA/RNA strands (purchased from Eurogentec) were firstly diluted in deionized water (18.2 M $\mathrm{M} . \mathrm{cm}$ resistivity) at $500 \mu \mathrm{M}$ (for monomolecular (i.e., F21T, F-Myc-T, F-TERRA, F-VEGF and F-duplex-T for FRET-melting experiments; F-Myc, F-22AG, F-SRC and F-duplex for pull-down assay; 22AG for CD) and bimolecular structures (i.e., ds12 and ds17)). All DNA structures were prepared in a Caco.K buffer, comprising $10 \mathrm{mM}$ lithium cacodylate buffer (pH 7.2) plus $10 \mathrm{mM} \mathrm{KCl} / 90 \mathrm{mM} \mathrm{LiCl}$ (except 22AG used for CD investigations, vide infra). Monomolecular structures were prepared by mixing $40 \mu \mathrm{L}$ of the constitutive strand $(500 \mu \mathrm{M})$ with $8 \mu \mathrm{L}$ of a lithium cacodylate buffer solution (100 mM, pH 7.2), plus $8 \mu \mathrm{L}$ of a $\mathrm{KCl} / \mathrm{LiCl}$ solution $(100 \mathrm{mM} / 900 \mathrm{mM})$ and 24 $\mu \mathrm{L}$ of water. Bimolecular structures were prepared by mixing $40 \mu \mathrm{L}$ of each constitutive strand $(500 \mu \mathrm{M})$ with $16 \mu \mathrm{L}$ of a lithium cacodylate buffer solution (100 mM, pH 7.2), plus $16 \mu \mathrm{L}$ of a $\mathrm{KCl} / \mathrm{LiCl}$ solution $(100 \mathrm{mM} / 900 \mathrm{mM}$ ) and $48 \mu \mathrm{L}$ of water. The actual concentration of each DNA sample was determined via dilution to $1 \mu \mathrm{M}$ (expressed in motif concentration) for 
monomolecular structures (i.e., $4 \mu \mathrm{L}$ in $996 \mu \mathrm{L}$ water) and bimolecular structures (i.e., $8 \mu \mathrm{L}$ in $992 \mu \mathrm{L}$ water) through UV spectral analysis at $260 \mathrm{~nm}$ (after $5 \mathrm{~min}$ at $90^{\circ} \mathrm{C}$ ) with the following molar extinction coefficient values provided by the manufacturer. The higher-order DNA/RNA structures were folded according to two procedures: (a) for the monomolecular architectures, solutions were heated $\left(90^{\circ} \mathrm{C}, 5 \mathrm{~min}\right)$, cooled on ice $(7 \mathrm{hrs})$ and then stored at least overnight $\left(4^{\circ} \mathrm{C}\right)$; (b) for the folding of bimolecular structures, the solutions were heated $\left(90^{\circ} \mathrm{C}, 5 \mathrm{~min}\right)$, gradually cooled $\left(65,60,55,50,40\right.$ and $\left.30^{\circ} \mathrm{C}(60 \mathrm{mn} / \mathrm{step}), 25^{\circ} \mathrm{C}(2 \mathrm{hr})\right)$ and then stored at least overnight $\left(4^{\circ} \mathrm{C}\right)$.

\section{Circular dichroism.}

CD spectra were recorded on a JASCO J-815 spectropolarimeter in a $10 \mathrm{~mm}$ path-length quartz semi-micro cuvette (Starna). CD spectra of 22AG alone (3 $\mu \mathrm{M})$, in either lithium cacodylate

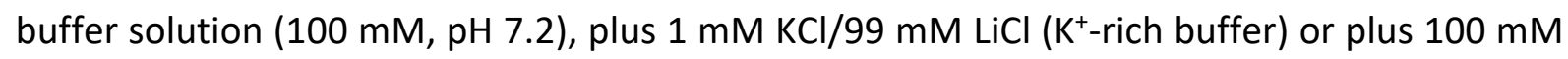
$\mathrm{LiCl}$ ( $\mathrm{Li}^{+}$-rich buffer) solution were recorded over a range of $210-320 \mathrm{~nm}$ (bandwidth $=1 \mathrm{~nm}, 1$ $\mathrm{nm}$ data pitch, $1 \mathrm{~s}$ response, scan speed $=500 \mathrm{~nm} \cdot \mathrm{min}^{-1}$, averaged over 5 scans, zeroed at $340 \mathrm{~nm})$ before and after incremental addition of either BioTASQ or BioCyTASQ (1, 2 and 5 mol. equiv.). Final data were treated with Excel and OriginPro ${ }^{\circledR} 9.1$.
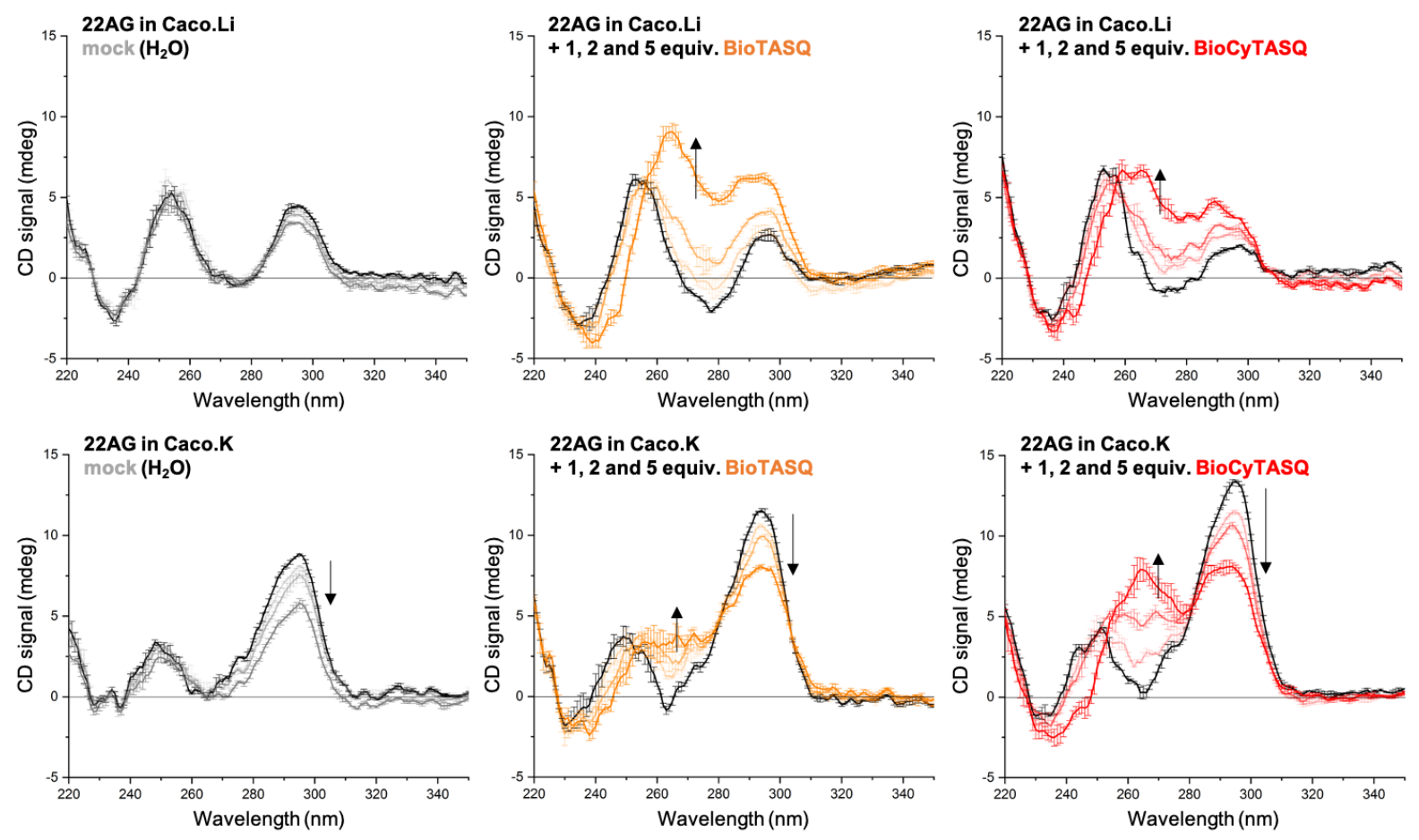

Figure S12. CD profiles of 22AG (either $\mathrm{K}^{+}$- or Li+-rich buffer) upon addition of BioTASQ or BioCyTASQ 